\title{
Pediatric Intradialytic Hypotension: Recommendations From the Pediatric Continuous Renal Replacement Therapy (PCRRT) Workgroup
}

Rupesh Raina ${ }^{1,3}$, Stephanie Lam ${ }^{2}$, Hershita Raheja ${ }^{3}$,Vinod Krishnappa ${ }^{3}$, Daljit Hothi ${ }^{4}$, Andrew Davenport ${ }^{5}$, Deepa Chand ${ }^{6}$, Gaurav Kapur ${ }^{7}$, Franz Schaefer ${ }^{8}$, Sidharth Kumar Sethi ${ }^{9}$, Mignon McCulloch ${ }^{10}$, Arvind Bagga ${ }^{11}$, Timothy Bunchman ${ }^{12}$, Brad Warady ${ }^{13}$

\author{
${ }^{1}$ Department of Nephrology, Cleveland Clinic Akron General and Akron Childrens Hospital, Akron, \\ Ohio, USA \\ ${ }^{2}$ Department of Pediatrics, Akron Childrens Hospital, Akron, Ohio, USA \\ ${ }^{3}$ Akron Nephrology Associates/Cleveland Clinic Akron General, Akron, Ohio, USA \\ ${ }^{4}$ Department of Paediatric Nephrology, Great Ormond Street Hospital, Great Ormond Street, London, \\ UK \\ ${ }^{5}$ UCL Centre for Nephrology, Royal Free Hospital , University College London, London, UK \\ ${ }^{6}$ Division of Pediatric Nephrology, University of Illinois college of Medicine, Peoria, Illinois, USA \\ ${ }^{7}$ Pediatric Nephrology and Hypertension, Children's Hospital of Michigan, Detroit, Michigan, USA \\ ${ }^{8}$ Pediatric Nephrology Division, Center for Pediatrics and Adolescent Medicine, Heidelberg \\ University Hospital, Heidelberg, Germany \\ ${ }^{9}$ Pediatric Nephrology \& Pediatric Kidney Transplantation, Kidney and Urology Institute, Medanta, \\ The Medicity Hospital, Gurgaon, India \\ ${ }^{10}$ Red Cross War Memorial Children's Hospital, University of Cape Town, Cape Town, South Africa \\ ${ }^{11}$ Division of Nephrology, Department of Pediatrics, All India Institute of Medical Sciences, New \\ Delhi, India \\ ${ }^{12}$ Pediatric Nephrology \& Transplantation, Children's Hospital of Richmond, Virginia \\ Commonwealth University, Richmond, Virginia, USA \\ ${ }^{13}$ Division of Nephrology, Dialysis and Transplantation, University of Missouri-Kansas City School \\ of Medicine; Division of Nephrology, Children's Mercy Kansas City, Kansas City, MO, USA
}

\section{Corresponding author}

Rupesh Raina, MD, FAAP, FACP, FASN, FNKF

Consultant Nephrologist

Adult-Pediatric Kidney Disease/Hypertension

Department of Nephrology

Cleveland Clinic Akron General and Akron Children's Hospital, Akron, Ohio, USA

Phone: $330-543-8950$

Fax: 330-543-3980

rraina@akronchildrens.org

raina@akronnephrology.com 


\begin{abstract}
Intradialytic hypotension (IDH) is a common adverse event resulting in premature interruption of hemodialysis, and consequently, inadequate fluid and solute removal. IDH occurs in response to the reduction in blood volume during ultrafiltration and subsequent poor compensatory mechanisms due to abnormal cardiac function or autonomic or baroreceptor failure. Pediatric patients are inherently at risk for IDH due to the added difficulty of determining and attaining an accurate dry weight. While frequent blood pressure monitoring, dialysate sodium profiling, ultrafiltration guided blood volume monitoring, dialysate cooling, hemodiafiltration, and intradialytic mannitol and midodrine have been used to prevent IDH, they have not been extensively studied in pediatric population. Lack of large-scale studies on IDH in children makes it difficult to develop evidence based management guidelines. Here we aim to review IDH preventative strategies in the pediatric population and outlay recommendations from the Pediatric Continuous Renal Replacement Therapy (PCRRT) Workgroup. Without strong evidence in the literature, our recommendations from the expert panel reflect expert opinion and serves as a valuable guide.
\end{abstract}

\title{
Key words
}

Intradialytic hypotension, children, blood pressure monitoring, sodium profiling, blood volume monitoring, dialysate cooling, mannitol, midodrine 


\section{$\underline{\text { Introduction }}$}

Despite medical and technological advances, intradialytic hypotension (IDH) continues to be a common adverse occurrence in pediatric population resulting in premature interruption of hemodialysis, and consequently, inadequate fluid and solute removal [1]. The blood pressure (BP) in children is defined by using age and gender adjusted $5^{\text {th }}$ percentile systolic blood pressure (SBP) measurements from the general population [2] and IDH is defined as less than the $5^{\text {th }}$ percentile of SBP measurements and is associated with clinical symptoms such as abdominal pain, nausea, vomiting, muscle cramps, restlessness, lightheadedness, syncope and anxiety [3]. IDH occurs in response to the reduction in blood volume during ultrafiltration and subsequent poor compensatory mechanisms due to abnormal cardiac function (left ventricular dysfunction, chamber remodeling, congenital heart diseases and arrhythmias) or autonomic or baroreceptor failure [1,3]. To maintain volume status, the body shifts fluid from the interstitial space to the intravascular space and increases heart rate, contractility and vascular tone. Plasma refilling, another essential factor in maintaining euvolemia, depends on oncotic, osmotic, and hydraulic gradients across vascular beds [3]. If ultrafiltration rates surpass plasma refilling rates, intravascular volume falls and hypotension results. Hematocrit levels, tissue hydration and arterial vasoconstriction all promote plasma refilling rates. Alterations in these factors during dialysis decrease the plasma refilling rate, resulting in hypotension [3]. IDH must be distinguished from dialysis disequilibrium syndrome (DDS), which is due to neurological deterioration seen in patients receiving hemodialysis especially during or immediately following initial treatment, but can also occur in subsequent treatments [4]. DDS mimics symptoms of raised intracranial pressure or acute hyponatremia and include restlessness, 
headache, confusion, and coma [4]. Other neurologic diagnoses must also be ruled out, as these symptoms are non-specific [4].

Pediatric patients are inherently at risk for IDH due to the added difficulty of determining and attaining an accurate dry weight [5]. While frequent blood pressure monitoring, dialysate sodium profiling, ultrafiltration guided blood volume monitoring, dialysate cooling, and intradialytic mannitol and midodrine have been used to prevent IDH, they have not been extensively studied [1].

To our knowledge, a consensus guideline of IDH preventative strategies in the pediatric population has not been conducted. Here we aim to review these interventions and outlay recommendations from the Pediatric Continuous Renal Replacement Therapy (PCRRT) Workgroup.

\section{$\underline{\text { Methods }}$}

\section{Literature search}

PubMed/Medline, Embase and Cochrane Database were searched to include all publications involving IDH in the pediatric population using a specific search strategy (Appendix A \& B). Returned citations were all reviewed individually for eligibility as per inclusion and exclusion criteria. Two reviewers independently assessed titles, abstracts, and full text articles for inclusion/exclusion criteria. A third independent reviewer conducted a similar assessment to overcome and settle any disagreements in data extraction. Inclusion criteria was studies involving hemodialysis, hemodiafiltration (HDF) and hemofiltration (HF) in pediatric patients (age 0-18 years), reporting of hypotension during dialysis, pre- and post-dialysis blood pressure measurement, difference between pre- and post-dialysis blood pressure measurements, variable dialysate electrolyte concentration or dialysate temperature, and use of volume management/ultrafiltration strategies or pharmacological treatment for 
IDH. Studies were excluded if they involved adult population ( $>18$ years), or had no mention of hypotension during dialysis. Tables were created to reflect subject data, dialysis parameters, and outcomes of the included studies.

\section{PCRRT workgroup}

The PCRRT workgroup is composed of international pediatric nephrology experts representing the treatment of diverse pediatric populations. The experts from the PCRRT workgroup and representatives from various international societies (Appendix C) participated in the consensus conference to discuss and provide recommendations on the management of IDH in the pediatric population. The consensus meeting took place at the $9^{\text {th }}$ International Conference on Pediatric Continuous Renal Replacement Therapy, presented by the PCRRT Foundation on September 2, 2017 at Disney's Yacht \& Beach Club Resorts, Lake Buena Vista, Orlando, Florida. Rationale, background, objectives, and statistical methods of this initiative were supported by the PCRRT workgroup. All the panel members were carefully selected by content expertise and potential conflicts of interests were disclosed. One panelist was an expert in epidemiology and guideline methodology. The chair of the PCRRT initiative was Dr. Timothy Bunchman (pediatric nephrologist, chair and founder of the PCRRT at Richmond, Virginia), while co-chairs were Dr. Rupesh Raina (adult and pediatric nephrologist Akron General Hospital Cleveland Clinic and Akron Children's hospital, Akron, Ohio) and Dr. Bradley Warady (pediatric nephrologist at Children's Mercy Hospital in Kansas City, Missouri).

\section{Evaluation of recommendation strengths and determination of evidence level}

The co-chairs completed the literature search, reviewed articles, extracted relevant data, and summarized findings, all of which were submitted to the workgroup for review and discussion. The workgroup was divided into subgroups, each of which reviewed an IDH 
preventative strategy in children and proposed recommendations. Voting by the entire workgroup was carried out to establish the strength of each of the recommendation statements using the modified Delphi method (Appendix D) [6]. Disagreements amongst panel members were resolved by quantifying votes using the RAND/UCLA Appropriateness Method and subsequently calculating a disagreement index [7]. The Grading of Recommendations, Assessments, Development and Evaluation (GRADE) was used to establish an evidence level for clinical recommendations (Appendix D) [8].

\section{$\underline{\text { Results of literature search }}$}

The initial search returned 471 citations from all databases, with 366 citations remaining after removal of duplicates; only 17 ( 1 being a randomized study) studies met our inclusion criteria (Figure 1). Relevant data pertaining to hemodialysis parameters in 11 studies, patient characteristics, and outcomes were extracted and summarized in Tables 1 and 2. Also, 6 studies involving HDF and HF were summarized in Table 3. A total of 145 patients were included in 11 studies involving hemodialysis with ages ranging from 2.2 to 18 years. Hemodialysis indications included both acute kidney injury and chronic kidney diseases. To avoid heterogeneity of reported findings, we have excluded AKI patients from analysis. Hemodialysis duration ranged between 3-4 hours with a frequency of 3-4 times/week. Both high flux and low flux dialysate membranes were used. Dialysate temperatures varied between $35^{0} \mathrm{C}$ to $37.5^{0} \mathrm{C}$. Acute kidney injury etiologies (20 patients) were acute tubular necrosis, hemolytic uremic syndrome (HUS), tumor lysis syndrome, and drug toxicity while chronic etiologies included focal segmental glomerulosclerosis, membranous glomerulonephritis, membranoproliferative glomerulonephritis, ANCA positive glomerulonephritis, polycystic kidney disease, renal dysplasia, and post-renal 
obstruction. Non-invasive blood volume monitoring was the most commonly reported modality for prevention of IDH and was used in 36\% (45/125) of patients.

A total of 33 patients were included in four studies involving HDF for IDH prevention and ages ranged from 2.4 to 16.3 years. HDF duration ranged between 3-4 hours/session and 3-6 times/week. Indications for HDF were malformative uropathy, Bardet Biedl syndrome, renal hypoplasia, corticoresistant nephrotic syndrome, nephronophtisis, Nail Patella syndrome, bilateral Wilms tumor, glomerular \& hereditary diseases, HUS, Henoch-Schoenlein syndrome, interstitial nephritis, cyclosporine A (CsA) toxicity after heart transplantation, Alport's syndrome, Wegener's granulomatosis, urethral valves and autosomal recessive polycystic kidney disease (ARPKD). HF for IDH prevention was used in two studies comprising 78 subjects, but patient population was mixed involving both adults and children with ages ranging from $12-78$ years.

\section{$\underline{\text { Discussion and consensus panel recommendations }}$}

\section{Preventative strategies}

Modalities for IDH prevention included dialysate sodium profiling, blood volume monitoring during ultrafiltration, dialysate cooling, HDF, HF and intradialytic administration of mannitol and midodrine.

\section{Blood volume monitoring during ultrafiltration}

A patient's dry weight refers to the lowest calculated weight a patient can reach following dialysis. If the weight falls below this value, the patient may experience symptomatic hypotension. Lack of standard dry weight calculations make accuracy difficult leading to miscalculations that can cause fluid overload or intravascular volume depletion [9]. Intradialytic blood volume monitoring (BVM) seeks to overcome this. BVM can be conducted through relative blood volume monitoring or hematocrit monitoring [9,5]. BVM 
technology includes a feedback loop based on "fuzzy logic" control systems, which allows the dialysis machine to monitor blood volume changes and adjust the ultrafiltration rate and/or dialysate sodium concentration [10]. In these control systems, a rapid decrease in blood volume (BV) leads to a decrease in the ultrafiltration rate and/or an increase in the dialysate sodium [10]. Ultrafiltration rate increases and dialysate sodium decreases when the $\mathrm{BV}$ is stable or decreases appropriately [10]. During hemodialysis sessions, the percentage change in BV can be continuously monitored through specialized devices that measure hemoglobin or hematocrit concentration. Newer dialysis machines have built-in BVM devices [9]. Innovative devices, such as Crit-Line ${ }^{\circledR}$ technology, measure hematocrit and oxygen saturation using photo optics that absorb or scatter light via erythrocytes [9]. The hematocrit measurement is inversely proportional to changes in blood volume allowing for real time management of symptomatic hypotension [5]. This method assumes that the total red cell volume remains constant throughout the treatment [5].

Real time intradialytic BVM using hematocrit measurements and a relative blood volume (RBV) slope helps achieve a balance between a patient's vascular refill and ultrafiltration (UF) rates [11]. Given the display features of the monitoring systems, intradialytic adjustments to the rate of fluid removal can be made; thereby potentially decreasing the frequency of IDH events [11]. Following hemodialysis initiation, the RBV value is routinely set to $100 \%$ and adjustments are made according to this initial value [11]. The critical relative blood volume (RBVcrit) is defined as the RBV value that indicates increased frequency of hypotensive episodes [11]. The exact RBVcrit varies among patients and should be individually established per patient. If values approach the RBVcrit, the BVM device automatically reduces the UF rate [12]. However, it is important to note that the set value of $100 \%$ is not fixed; the fluid gain between dialysis treatments varies and is further 
influenced by inter-current illness and unique individual factors [10,13]. Furthermore, as reported by Mitra et al, during ultrafiltration, BV increases due to capillary vasoconstriction, resulting in vascular refill of the of the macrocirculation from the microcirculation (intravascular refill) [14]. These dynamic changes along with increase in central BV during ultrafiltration underestimate the changes in systemic hematocrit and blood volume; the BVM concept assumes a constant circulating blood mass (volume) and component (hematocrit) $[14,13]$

The European Hemodialysis Guidelines for children recommend UF rates of $1.5+/$ $0.5 \%$ of body weight per hour and a maximum UF volume of $5 \%$ of patient's dry weight per a 3-4 hour conventional dialysis session without sodium and UF profiles or temperature control [15]. Hothi et al compared a constant UF rate to varied UF patterns (decreasing step pattern, an alternating high/low UF rate and a decreasing linear pattern) in 10 patients. The UF profiles were no better than using constant ultrafiltration rate [16]. In another study, Hothi et al retrospectively reviewed records of 74 children and observed a correlation between RBV reduction and intradialytic adverse effects [17]. The gradient of the RBV curve during the first hour of dialysis treatment and the changes in intradialytic heart rate were the strongest predictors of intradialytic complications [17]. Fadel et al noted that the assessment of dry weight based on non-invasive monitoring (NIVM) of hematocrit led to a significant reduction in the frequency of intradialytic-morbid events (light headedness, nausea, vomiting or cramps) and associated hypotension [9]. In a retrospective study of pediatric intensive care unit (PICU) patients requiring hemodialysis for acute kidney injury, Merouani et al found BVM patients versus non-BVM patients had no difference in frequency of hypotension [5]. However, the mean UF volume was significantly higher in the BVM group compared to the controls ( $48 \pm 27$ vs. $33 \pm 26 \mathrm{~mL} / \mathrm{kg} ; \mathrm{P}<0.001)$. They 
concluded that strict BVM allowed for an increased UF volume per session without affecting the incidence of hypotensive episodes [5]. Levtchenko et al found that BV changes, displayed by Crit-Line ${ }^{\circledR}$ technology, were in fact related to changes in patient's weight during hemodialysis sessions [18]. Therefore, an approximation of dry weight in children using non-invasive monitoring technology can aid in preventing intradialytic adverse events [18].

\section{Recommendations from the consensus panel for blood volume monitoring}

All recommendations from the consensus conference including strengths and evidence level based on the methods described previously are summarized in Table 4. CritLine ${ }^{\circledR}$ monitoring is recommended for acute and chronic pediatric hemodialysis treatments. The panel recognizes Crit-Line ${ }^{\circledR}$ monitoring may not be available worldwide. While level of evidence is low, a majority of panel members strongly recommended BVM in the management of IDH based on clinical experience. A physician order for use of the CritLine ${ }^{\circledR}$ monitor must be in place before hemodialysis initiation as the Crit-Line ${ }^{\circledR}$ blood chamber cannot be installed after the treatment has started. Use of the Crit-Line® monitor is conducted in the following manner:

Procedure: Begin by priming the circuit with the disposable blood chamber in place between the arterial header and the arterial line and attach the clip to blood chamber. Do not monitor UF profiling simultaneously with Crit-Line ${ }^{\circledR}$ monitoring. Set the hematocrit (Hct) limit at 2 Hct units above the starting Hct level. If the patient remains asymptomatic, the Hct level can be increased slowly 1 unit at a time during the session. Note, priming the dialysis circuit with blood will limit the usefulness of BVM. 
Recommended BV Change: 3-5\% per hour, up to $8 \%$ during the first hour, then $4 \%$ per hour in the subsequent hours with maximal total BV change of $16 \%$ at the end of the 4-hour treatment.

Adjustments during Treatment: Ultrafiltration goals and adjustment recommendations from the consensus panel are summarized in Table 4 . The Crit-Line ${ }^{\circledR}$ technology displays the slopes and profiles categorized as Profiles A, B, or C (Figure 2).

- Profile A - Patient's plasma refill rate is occurring at the same or at an increased rate compared to the ultrafiltration rate.

- Profile B - No changes needed given the gradual slope and balance found between a high ultrafiltration rate and avoidance of intradialytic symptoms.

- Profile C - Patient's display shows a steep slope representing a rapid decrease in blood volume and an increased risk of intradialytic symptoms.

Refill Assessment: At the end of treatment, if Hct decreases $>0.5 \%$ or BV increases $>1.5 \%$, refill is present (patient not at dry weight). This assessment is based on clinical experience. Normal oxygen saturation ranges: Arteriovenous fistula/arteriovenous graft (AVF/AVG) > 90\%, central venous catheter (CVC) $60-80 \%$.

Documentation: Use clinical markers (press arrow keys) to mark all events/changes in treatment. Print the session document and place in patient's chart. If unable to print, chart the data ( $\mathrm{Hb}, \mathrm{Hct}$, Sat, BV change) on the patient's run sheet at the start, hourly, and at the end of the session.

\section{Dialysate sodium profiling}

The majority of pediatric dialysis patients are fluid and salt overloaded, left ventricular mass index is increased in a substantial number, thus the primary goal is to adequately balance fluid and salt homeostasis, which in many cases meant to remove salt 
especially in adolescent patients. In case IDH develops or the critical RBV is reached, prolongation of dialysis duration may be required rather than adding sodium to prevent IDH, which in the long run may increase thirst and create a vicious circle. Consistent automated BV monitoring almost inevitably results in prolongation of dialysis time. Changes to dialysate sodium concentration should be made to maintain plasma osmolality with the goal to shift plasma water into the intracellular compartment [19]. Sodium profiling adjusts the sodium content of dialysate to directly influence the plasma sodium levels (Figure 3) $[19,20]$. Generally, the intracellular volume (ICV) constitutes $65 \%$ of total body water, whereas the extracellular volume (ECV) constitutes 35\% [21]. Active transport and permeability of cell membranes equilibrate the electrolyte concentration between the intracellular and extracellular compartments [21]. Fluid shifts and changes in osmotic gradients between the intracellular and extracellular compartments contribute to intradialytic hypotension. By controlling the dialysate sodium concentration and water movement across the cell membrane, the number of hypotensive episodes can be reduced [22].

Although a complete review of the effects of dialysate sodium profiling is beyond the scope of this review, the authors would like to underscore its importance to IDH and the limitations of the available studies $[23,24]$. Pediatric practice differs from adult practice in that children on dialysis more commonly have underlying sodium losing nephropathies [25]. Sodium tissue stores in these patients may differ from adults and children with glomerular diseases. As such, hemodynamic responses to the changes in dialysate sodium can differ among patients [23]. Unfortunately, this granularity of patient information is not provided in the published clinical studies and may account for some of the differences reported among studies. Nevertheless, patients undergoing hemodialysis with a dialysate sodium concentration lower than their serum sodium are at higher risk for IDH and associated 
symptoms [26]. In contrast, higher dialysate to serum sodium concentration increases risk for a positive sodium and water balance leading to a higher risk for hypertension, a known risk factor for cardiovascular morbidity in patients with chronic kidney disease [26]. According to Tangvoraphonkchai and Davenport, the variable effects on blood pressure control and adverse intradialytic events associated with lower dialysate sodium concentrations may be partially explained by patient selection and their differences in dietary sodium intake, urinary sodium losses, and sodium stores in the body [23]. Additionally, it is important to note that exact "high" and "low" dialysate sodium concentrations are not quantitatively defined; manufacturers allow variation in dialysate sodium concentration and in dialysis machine calibration by measuring dialysate conductivity (determined mainly by sodium and chloride) $[23,25,26]$. These factors further confound the prescribed versus delivered dialysate sodium to the patient.

Three dialysate sodium profiles exist in adults: increasing, alternating, and decreasing profiles (Table 5). Although each profile has potential benefits for certain intradialytic symptoms, published work suggests the decreasing sodium profile most effectively prevents or modifies IDH [21]. An increasing sodium profile, which is less commonly used, has reportedly reduced muscle cramps in patients, but may actually worsen symptomatic hypotension [22]. This profile conserves plasma volume near the end of treatment when ultrafiltration remains high; however, this may worsen the decline in plasma osmolality during the first portion of treatment and increase the risk of intradialytic hypotension [19]. Thus, the increasing sodium profile is recommended for patients with muscle cramps and less susceptible to hypotension [21]. An alternating sodium profile using hypernatric and hyponatric dialysate introduces alternating fluid shifts across the cellular membrane to aid uremic toxin transport out of the cells via solvent drag. This profile may 
decrease the risk of disequilibrium syndrome, but there is no significant effect reported on hypotension [19].

Decreasing sodium profiling can be done linearly, step-wise, or exponentially. The dialysate sodium concentration is highest at the start of treatment and gradually decreases until the end of the treatment (Figure 3) [19]. At the start of hemodialysis, the solute removal rate is greatest; thus, a higher dialysate sodium concentration counteracts the rapid decline in the concentration of molecules like urea and minimizes the osmotic effect [19]. As the osmolality gradient decreases toward the end of dialysis, the low dialysate sodium promotes the diffusive clearance of the accumulated sodium load [19]. The decreasing profile also generally results in less interdialytic weight gain, which contributes to fewer hypotensive episodes [19].

Sodium profiling to prevent IDH in pediatric populations has not been studied extensively. Hothi et al compared linear versus step sodium profiling in 10 patients with an initial dialysate sodium concentration of $148 \mathrm{mmol} / \mathrm{L}$, with decreases to $138 \mathrm{mmol} / \mathrm{L}$ at the end of the dialysis session [16]. Linear sodium profiling achieves the final sodium concentration through a steady decline of the dialysate sodium concentration throughout the hemodialysis treatment. In step sodium profiling, the initial sodium concentration remains constant until 30 minutes prior to the end of the hemodialysis session, at which point the concentration of sodium is decreased to a final level of $138 \mathrm{mmol} / \mathrm{L}[16]$. While this study did not show a significant difference between linear and step sodium ramping in preventing intradialytic symptoms, the linear profile did increase the odds of hypotensive episodes or premature discontinuation of treatment by $27 \%$ [16]. The authors concluded that the step ramping reduced the odds of intradialytic hypotension when compared to a linear profile [16]. 


\section{Recommendations from the consensus panel for dialysate sodium profiling}

The consensus panel recommended decreasing sodium profiling to prevent or reduce IDH events when compared to increasing or alternative sodium profiling. Step sodium profiling is better than linear sodium profiling in reduction of hypotensive events in children. The panel members felt that the modality is limited by delivery of the prescribed versus the delivered dialysate sodium to the patient and is appropriate only in the presence of baseline hyper or hypo osmolar states. Sodium losses by native urine output should be taken into account. Sodium modeling remains a clinical tool with low level of evidence for benefit in children (Table 4).

\section{Cooling dialysate}

Published literature regarding cooling dialysate for the management of IDH in pediatric populations is limited. Cooling dialysate to less than $36.5 \mathrm{C}$ increases hemodynamic stability in adult studies [27]. However, the same concept cannot be applied to the pediatric population. While dialysate cooling is potentially beneficial, patient comfort may preclude its usefulness. A study involving 28 children by Hegazy et al found that lowering the dialysate temperature to $35^{\circ} \mathrm{C}$ improved heart rate variability, tolerance to ultrafiltration and reduced IDH events [27].

\section{Consensus panel recommendations for cooling dialysate}

The consensus panel discussed cooling dialysate recommendations to reduce/prevent IDH events in pediatric populations based on current evidence. Without a clear consensus, a majority of panel members consider use of cooling dialysate in cases of baseline temperature instability and in small children who may have disproportionate extracorporeal volume (with inherent cooling) compared to intravascular blood volume. There is low level of evidence for lowering the dialysate temperature for the patient with repeated episodes of IDH (Table 4). 


\section{Midodrine and mannitol}

In addition to the aforementioned methods, prophylactic mannitol and rescue midodrine may be used in IDH management and are preferred over saline boluses [16]. Mannitol, an osmotically active solute, produces a more sustained oncotic effect than sodium and does not leak into the interstitium [28]. Midodrine prevents venous pooling and mediates central blood pressure through its alpha-1 adrenergic agonist activity, which constricts both arterial and venous capacitance [28].

Hothi et al studied 6 patients susceptible to intradialytic symptoms or IDH who received sequential dialysis (explained later) and prophylactic mannitol either at a dose of 1 $\mathrm{g} / \mathrm{kg}$ in the first hour of first dialysis session of the week or $0.5 \mathrm{~g} / \mathrm{kg}$ two times/week [28]. This study reviewed the value of sequential dialysis, intradialytic mannitol and midodrine in these patients. In patients with IDH, $2.5 \mathrm{mg}$ of oral midodrine was administered and repeated if IDH failed to improve within 30 minutes or if systolic blood pressure fell below $75 \mathrm{mmHg}$ with a maximum total cumulative dose of $7.5 \mathrm{mg}$ per 3-hour dialysis session [28]. Midodrine was not administered during last 30 min of a dialysis session regardless of blood pressure changes [28]. Of the 399 sessions, intradialytic mannitol was administered in 57 (17\%), sequential dialysis in $44(11 \%)$ and midodrine in 20/144 (14\%) dialysis sessions [28]. The combination of mannitol and sequential dialysis decreased the odds of IDH and intradialytic symptoms (abdominal pain, cramps, headaches, loss of consciousness, or change in behavior) [28]. Additionally, premature cessation of dialysis decreased by $50 \%$. No intradialytic symptoms were seen with midodrine use [28]. In a separate study, Hothi et al (2008), reported that while mannitol reduced the frequency of intradialytic symptoms, it did not prevent intradialytic hypotension [16]. Blowey et al reported the case of an 18-year-old male with Bardet-Biedl syndrome who benefited from $10 \mathrm{mg}$ of midodrine 45 minutes prior 
to the start of hemodialysis [29]. The patient continued midodrine for 4 months at which point midodrine was tapered and discontinued with no recurrence of IDH [29].

\section{Recommendations from the consensus panel regarding the use of midodrine and} mannitol

Due to lack of adequate clinical studies testing the efficacy of midodrine and mannitol in the management of IDH, the consensus panel members recommended the usage of these drugs could be appropriate in the face of hypo-osmolality or presence of inherent blood pressure instability that is responsive to vasopressors. The level of evidence supporting its efficacy, however, is very low (Table 4).

Procedure: If IDH is unresponsive to UF goal adjustments per Crit-line ${ }^{\circledR}$ monitoring, the following order should be placed before starting dialysis:

- $5 \mathrm{ml} / \mathrm{kg}$ of saline bolus

- Mannitol $1 \mathrm{~g} / \mathrm{kg}$ in the first hour of first dialysis session of the week or $0.5 \mathrm{~g} / \mathrm{kg}$ two times/week

- Midodrine $2.5 \mathrm{mg}$ and repeated if BP failed to improve within $30 \mathrm{~min}$ or if the systolic BP dropped to $<75 \mathrm{mmHg}$ with a maximum cumulative dose of $7.5 \mathrm{mg} / 3$ hour dialysis session. No midodrine during last 30 min of dialysis.

\section{Bioelectrical Impedance Analysis}

As noted previously, dry weight estimation of pediatric patients can be difficult as normal growth and weight gain need to be considered. Underestimating dry weight leads to hypovolemia and IDH symptoms while overshooting dry weight results in fluid overload leading to increased risk for hypertension, pulmonary edema, congestive heart failure, and left ventricular hypertrophy [30]. Bioelectrical Impedance Analysis (BIA) noninvasively evaluates changes in total body water (TBW) before, during, and after hemodialysis. BIA 
estimates body composition and fluid status to better calculate dry weight [30]. Brooks et al used BIA variables and cardiovascular parameters (blood pressure and heart rate) to predict relative changes in body fluid status and interdialytic weight gain [30]. This study suggested using BIA during dialysis to detect cardiovascular instability prior to development of IDH symptoms [30]. The consensus panel recommended against BIA in the management of IDH due to the scarcity of efficacious studies in pediatrics. Evidence for use is very low (Table 4).

\section{Hemodifiltration}

Hemodiafiltration is a technique that uses convective clearance in combination with diffusive clearance that is used in standard hemodialysis in order to provide more hemodynamic stability in addition to middle and small molecular clearance [31]. Compared to standard hemodialysis, HDF has been shown to improve hemodynamic stability and mortality rates in adult patients [1]. However, limited data is available in the literature to support this benefit in children. Thumfart et al in their study involving seven children found that both nocturnal HDF and nocturnal hemodialysis reduced IDH events compared to conventional hemodialysis [31]. In another recent study by Zarauza-Santovena et al involving seven pediatric patients, online-HDF reduced IDH events $(0.21$ episodes/patient/week vs $0.58 ; \mathrm{p}=0.028$ ) compared to conventional HD [32]. Further, a study by Dheu et al demonstrated a unique BVM curve that predicts the risk of hypotension during dialysis using online-HDF and BVM in 14 children [33]. In this study, normal BVM curve was observed in $91 \%$ of the dialysis sessions and described as initial rapid fall of BV $<8 \%$ in the first hour followed by progressive attainment of a plateau not less than a $12 \% \mathrm{RBV}$ decrease while the BVM curve that indicates the risk of IDH was observed in only $4 \%$ of the sessions and described as initial BV fall of $>8 \%$ without reaching a stable plateau [33]. In a pilot study involving five children, Fischbach et al demonstrated the benefit of daily online- 
HDF (3 hrs, 6 times/week) compared to the standard online-HDF (4 hrs, 3 times/week) [34]. With the daily online-HDF, increased dialysis dose was achieved in addition to better tolerability and blood pressure control without any complications [34]. Significant regression in left ventricular hypertrophy and improvement in left ventricular systolic function were also observed with the daily online-HDF [34]. Because of these beneficial effects of HDF, the majority of consensus panel members recommend using HDF as modality of choice in children with hemodynamic instability and frequent IDH episodes, although available scientific evidence is low (Table 4).

\section{Other modalities for IDH prevention}

Other interventions in management of IDH include: ultrafiltration profiling, sequential dialysis, biofeedback, quotidian hemodialysis and ultrafiltration rate adjustment based on body surface area. Limited or absent evidence for these techniques in children exists.

Ultrafiltration profiling: Ultrafiltration profiling adjusts the UF rate, thereby controlling the amount of fluid removed throughout the dialysis session. Ultrafiltration profiles such as linear decrease, stepwise decrease and alternating high/low ultrafiltration profiling have been tested in children. However, no significant benefit was observed with the use of UF profiling compared to constant UF rate [16]. The consensus panel recommended against this method in children (Table 4).

Sequential dialysis: Sequential dialysis is hemodialysis following pure UF, which removes a large amount of isosmotic fluid [28]. Hothi et al studied the effects of 30 min and 1 hour sequential dialysis during 3 and 4-hour hemodialysis sessions, respectively, in children and found significant reduction in intradialytic symptoms, but not in hypotensive episodes [28]. Expert panel members felt sequential dialysis may be appropriate in the setting of 
proportionally more fluid removal needs as opposed to solute clearance. However, evidence for its efficacy in IDH prevention is very low (Table 4).

Biofeedback: Biofeedback controls UF rate and clearance based on negative feedback from the monitoring system [1]. In children, biofeedback systems function by UF algorithms that control UF rates and dialysate conductivity based on relative blood volume (RBV) changes to maintain RBV within the pre-set range during dialysis [35]. Using a constant dialysate sodium of $140 \mathrm{mmol} / \mathrm{l}$, Jain et al found that reductions of RBV $<8 \% / \mathrm{hr}$ in the first hour and $<4 \%$ thereafter is a safe approach to UF rate adjustment [35]. Alternatively, Hothi et al utilized a range of dialysate sodium and UF rate adjustments and concluded that a cutoff threshold of $88 \%$ RBV in the first hour, $84 \%$ by the second hour, and $82 \%$ by the third hour were better predictors of intradialytic complications [17]. The expert panel felt that the evidence is low and recommended biofeedback technology use may be considered in the setting of a child or family that prefers a less invasive feedback approach. This approach requires consistent and continual interaction with family (Table 4).

Quotidian hemodialysis: Quotidian hemodialysis is characterized by slow and gradual removal of fluid from the body, which consists of short, frequent dialysis sessions to maintain fluid balance and decrease intra and interdialytic adverse events [1]. Short daily dialysis involves 2-3 hour dialysis sessions, 5 to 6 times per week whereas frequent dialysis involves 4-5 hour dialysis session every other day. While published data in children is limited, this method can decrease intradialytic adverse events (hypotension and post-dialysis fatigue) [36]. While the consensus panel felt that the evidence is very low, this may be a reason why home hemodialysis is better tolerated than in-center hemodialysis (Table 4).

\section{Body surface area based ultrafiltration rate adjustment}


There is no published literature regarding body surface area based ultrafiltration rate adjustment in children. Previous studies have discussed UF rates adjusted to body mass/weight. Daugirdas et al found it advantageous to adjust UF rates to body surface area rather than body mass [37]. Due to the lack of clinical studies testing the efficacy of body surface area based UF rate adjustments in children, the consensus panel recommended against the usage of this method (Table 4).

\section{Hemofiltration}

Hemofiltration is a technique that uses convective clearance and has been shown to be beneficial in preventing IDH events in very few studies that contained both adult and pediatric patients $[38,39]$. Baldamus et al involving six end stage renal disease patients (1763 years age range) showed that HF decreased IDH events compared to hemodialysis [38]. In another study by Quellhorst et al comprising 72 patients (12-78 years age range), the major reasons for switching from hemodialysis to HF were hypotension, hypertension and/or frequent over-hydration events, which indicates more hemodynamic stability with HF [39]. Due to scarcity of scientific evidence, consensus panel recommends against the use of HF technique for IDH prevention in children (Table 4).

\section{$\underline{\text { Limitations }}$}

Limitations of this review include a small number of studies, differences in illness severity, and varying methods among selected studies. Illness severity ranged from stable patients receiving outpatient hemodialysis to critically ill requiring hemodialysis in the intensive care unit. There were multiple methods used in each study, making comparison among them difficult. Furthermore, most of the studies were performed using Fresenius 2008 dialysis machines, which in view of the fact that many centers now use Fresenius $4008 / 5008$ machines and that the pediatric version of the Fresenius 6008 machine is 
currently licensed sheds light on another difficulty of the reviewed scientific evidence. In addition, only one study used NxStage System One, and no studies tested other dialysis machines such as Gambro, Nipro, Baxter, Dialife, SWS hemodialysis machines etc., which adds to the difficulty of interpreting available scientific evidence. Future large-scale studies are necessary to further delineate the most effective methods for prevention of IDH.

\section{Conclusions}

IDH remains a common complication of hemodialysis in children with a lack of effective therapeutic intervention. The associated lack of large-scale studies on IDH in the pediatric population makes it difficult to develop evidence based management guidelines. However, our recommendations from the expert panel serves as a valuable guide. Noninvasive monitoring of hematocrit and lowering the dialysate temperature are, at present, the most effective clinical approaches for the management of IDH in children.

Funding/Support: None

Conflict of interest: The authors have no conflicts of interest to disclose

\section{Acknowledgments}

We thank Ms. Jennifer Clark, Medical Writer, Akron Children's Hospital for her assistance in language editing. 


\section{References}

1. Hayes W, Hothi DK (2011) Intradialytic hypotension. Pediatric Nephrology 26 (6):867-879

2. Blumenthal S, Epps RP, Heavenrich R, Lauer RM, Lieberman E, Mirkin B, Mitchell SC, Boyar Naito V, O'Hare D, McFate Smith W, Tarazi RC, Upson D (1977) Report of the task force on blood pressure control in children. Pediatrics 59 (5 2 suppl):I-ii, 797-820

3. Hothi DK (2009) An Investigation Into The Mechanisms, Consequences and Moderators of Intradialytic Hypotension in Paediatric Haemodialysis University College London, 4. Arieff Al (1994) Dialysis disequilibrium syndrome: Current Concepts on pathogenesis and prevention. Kidney International 45 (3):629-635. doi:10.1038/ki.1994.84

5. Merouani A, Kechaou W, Litalien C, Ducruet T, Jouvet P (2011) Impact of blood volume monitoring on fluid removal during intermittent hemodialysis of critically ill children with acute kidney injury. Nephrology Dialysis Transplantation 26 (10):3315-3319

6. Lavergne V, Nolin TD, Hoffman RS, Roberts D, Gosselin S, Goldfarb DS, Kielstein JT, Mactier R, Maclaren R, Mowry JB, Bunchman TE, Juurlink D, Megarbane B, Anseeuw K, Winchester JF, Dargan PI, Liu KD, Hoegberg LC, Li Y, Calello DP, Burdmann EA, Yates C, Laliberte M, Decker BS, Mello-Da-Silva CA, Lavonas E, Ghannoum M (2012) The EXTRIP (EXtracorporeal TReatments In Poisoning) workgroup: guideline methodology. Clin Toxicol (Phila) 50 (5):403-413. doi:10.3109/15563650.2012.683436

7. Fitch K, Bernstein SJ, Aguilar MD, Burnand B, LaCalle JR, Lázaro P, Loo Mvh, McDonnell J, Vader JP, Kahan JP (2001) The RAND/UCLA Appropriateness Method User's Manual. Rand Publication.

https://www.rand.org/content/dam/rand/pubs/monograph reports/2011/MR1269.pdf.

8. Thornton J, Alderson P, Tan T, Turner C, Latchem S, Shaw E, Ruiz F, Reken S, Mugglestone MA, Hill J, Neilson J, Westby M, Francis K, Whittington C, Siddiqui F, Sharma T, Kelly V, Ayiku L, Chamberlain K (2013) Introducing GRADE across the NICE clinical guideline program. Journal of clinical epidemiology 66 (2):124-131.

doi:10.1016/j.jclinepi.2011.12.007

9. Fadel FI, Makar SH, Eskander AE, Aon AH (2014) Decreasing intra-dialytic morbid events and assessment of dry weight in children on chronic hemodialysis using non-invasive changes in hematocrit. Saudi journal of kidney diseases and transplantation : an official publication of the Saudi Center for Organ Transplantation, Saudi Arabia 25 (5):1030-1037 10. Davenport A (2011) Using dialysis machine technology to reduce intradialytic hypotension. Hemodial Int 15 Suppl 1:S37-42. doi:10.1111/j.1542-4758.2011.00600.x 11. Reddan DN, Szczech LA, Hasselblad V, Lowrie EG, Lindsay RM, Himmelfarb J, Toto RD, Stivelman J, Winchester JF, Zillman LA, Califf RM, Owen WF, Jr. (2005) Intradialytic blood volume monitoring in ambulatory hemodialysis patients: a randomized trial. Journal of the American Society of Nephrology : JASN 16 (7):2162-2169. doi:10.1681/asn.2004121053

12. Fresenius Medical Care Crit-Line III User Manuel. https://fmcna.com/wpcontent/uploads/documents/CL80020031 Rev H.pdf.

13. Davenport A (2009) Can advances in hemodialysis machine technology prevent intradialytic hypotension? Semin Dial 22 (3):231-236. doi:10.1111/j.1525-

139X.2009.00614.x 
14. Mitra S, Chamney P, Greenwood R, Farrington K (2004) The relationship between systemic and whole-body hematocrit is not constant during ultrafiltration on hemodialysis. Journal of the American Society of Nephrology : JASN 15 (2):463-469

15. Fischbach M, Edefonti A, Schröder C, Watson A (2005) Hemodialysis in children: general practical guidelines. Pediatric Nephrology 20 (8):1054-1066. doi:10.1007/s00467-005-1876y

16. Hothi DK, Harvey E, Goia CM, Geary DF (2008) Evaluating methods for improving ultrafiltration in pediatric hemodialysis. Pediatric Nephrology 23 (4):631-638

17. Hothi DK, Harvey E, Goia CM, Geary D (2008) Blood-volume monitoring in paediatric haemodialysis. Pediatric Nephrology 23 (5):813-820

18. E. Levtchenko, D. Creemers, D.V. Schaijk, I. Rijbroek, Schroder. C (2003) Use of NIMH for determination of dry weight and prevention of dialysis associated morbidity in children. Hemodialysis International 7 (1):104

19. Petitclerc T, Trombert JC, Coevoet B, Jacobs C (1996) Electrolyte modelling: sodium. Is dialysate sodium profiling actually useful? Nephrology, dialysis, transplantation : official publication of the European Dialysis and Transplant Association - European Renal Association 11 Suppl 2:35-38

20. Advanced Renal Education Program: Sodium Modelling. (2015) Fresenius Medical Care. http://advancedrenaleducation.com/content/sodium-modeling.

21. Mann H, Stiller S (2000) Sodium modeling. Kidney international Supplement 76:S79-88

22. Sadowski RH, Allred EN, Jabs K (1993) Sodium modeling ameliorates intradialytic and interdialytic symptoms in young hemodialysis patients. Journal of the American Society of Nephrology 4 (5):1192-1198

23. Tangvoraphonkchai K, Davenport A (2018) Why does the choice of dialysate sodium concentration remain controversial? Hemodial Int. doi:10.1111/hdi.12645

24. KDOQI (2015) KDOQI Clinical Practice Guideline for Hemodialysis Adequacy: 2015 update. American journal of kidney diseases : the official journal of the National Kidney Foundation 66 (5):884-930. doi:10.1053/j.ajkd.2015.07.015

25. Hecking M, Wong MMY, Port FK, Robinson BM, McCullough KP (2017) Regional Differences in the Associations Between Prescribed Dialysate Sodium Concentration and Interdialytic Weight Gain in the Dialysis Outcomes and Practice Patterns Study. American journal of kidney diseases : the official journal of the National Kidney Foundation 70 (3):450-451. doi:10.1053/j.ajkd.2017.03.024

26. Hecking M, Kainz A, Horl WH, Herkner H, Sunder-Plassmann G (2011) Sodium setpoint and sodium gradient: influence on plasma sodium change and weight gain. American journal of nephrology 33 (1):39-48. doi:10.1159/000322572

27. Hegazy RA, Sharaf IA, Fadel F, Bazaraa H, Esam R (2011) Heart rate variability in pediatric patients on regular hemodialysis. Europace Conference: EHRA Europace 13 (no pagination)

28. Hothi DK, Harvey E, Goia CM, Geary D (2009) The value of sequential dialysis, mannitol and midodrine in managing children prone to dialysis failure. Pediatric Nephrology 24 (8):1587-1591

29. Blowey DL, Balfe JW, Gupta I, Gajaria MM, Koren G (1996) Midodrine efficacy and pharmacokinetics in a patient with recurrent intradialytic hypotension. American Journal of Kidney Diseases 28 (1):132-136 
30. Brooks ER, Fatallah-Shaykh SA, Langman CB, Wolf KM, Price HE (2008) Bioelectric impedance predicts total body water, blood pressure, and heart rate during hemodialysis in children and adolescents. J Ren Nutr 18 (3):304-311. doi:10.1053/j.jrn.2007.11.008

31. Thumfart J, Puttkamer CV, Wagner S, Querfeld U, Muller D (2014) Hemodiafiltration in a pediatric nocturnal dialysis program. Pediatric Nephrology 29 (8):1411-1416

32. Zarauza-Santovena A, Alonso-Melgar A, Gonzalez-Perez P, Lopez-Font M, HernandezZuniga L, Ruiz-Hernandez F, Fernandez-Camblor C, Melgosa-Hijosa M, Espinosa-Roman L (2015) Safety and efficacy of online-hemodiafiltration in pediatric population. Pediatric Nephrology 30 (9):1639-1640

33. Dheu C, Terzic J, Menouer S, Fischbach M (2009) Importance of the curve shape for interpretation of blood volume monitor changes during haemodiafiltration. Pediatric Nephrology 24 (7):1419-1423

34. Fischbach M, Terzic J, Laugel V, Dheu C, Menouer S, Helms P, Livolsi A (2004) Daily online haemodiafiltration: a pilot trial in children. Nephrology, dialysis, transplantation : official publication of the European Dialysis and Transplant Association - European Renal Association 19 (9):2360-2367. doi:10.1093/ndt/gfh403

35. Jain SR, Smith L, Brewer ED, Goldstein SL (2001) Non-invasive intravascular monitoring in the pediatric hemodialysis population. Pediatric Nephrology 16 (1):15-18

36. Goldstein SL, Silverstein DM, Leung JC, Feig DI, Soletsky B, Knight C, Warady BA (2008) Frequent hemodialysis with NxStage system in pediatric patients receiving maintenance hemodialysis. Pediatric nephrology (Berlin, Germany) 23 (1):129-135. doi:10.1007/s00467007-0649-1

37. Daugirdas JT, Schneditz D (2017) Hemodialysis Ultrafiltration Rate Targets Should Be Scaled to Body Surface Area Rather than to Body Weight. Semin Dial 30 (1):15-19. doi:10.1111/sdi.12563

38. Baldamus CA, Schoeppe W, Koch KM (1978) Comparison of haemodialysis (HD) and post dilution haemofiltration (HF) on an unselected dialysis population. Proceedings of the European Dialysis \& Transplant Association 15:228-235

39. Quellhorst E (1983) Long-term follow up in chronic hemofiltration. International Journal of Artificial Organs 6 (3):115-120 
Table 1. Patient characteristics, indications, intervention used, \& outcomes.

\begin{tabular}{|c|c|c|c|c|c|c|c|}
\hline Study & $\mathbf{N}$ & $\begin{array}{l}\text { Mean } \\
\text { Age }\end{array}$ & Indications (number of patients) & $\begin{array}{l}\text { Definitio } \\
n \text { of IDH }\end{array}$ & $\begin{array}{l}\text { Interv } \\
\text { ention } \\
\text { Used }\end{array}$ & Outcome & Conclusion \\
\hline $\begin{array}{l}\text { Hothi et al, } \\
2008 \\
\text { Prospective, } \\
\text { observationa } \\
\text { 1, single } \\
\text { center study } \\
\text { over a period } \\
\text { of } 8 \text { months }\end{array}$ & 10 & $\begin{array}{l}12.8+/- \\
2.93 \\
\text { years }\end{array}$ & $\begin{array}{l}\text { Focal segmental glomerulosclerosis } \\
\text { (1) } \\
\text { Autosomal recessive polycystic } \\
\text { kidney disease (1) } \\
\text { Renal dysplasia (3) } \\
\text { Chronic drug toxicity and BK virus } \\
\text { nephropathy secondary to cardiac } \\
\text { transplant (1) } \\
\text { Membranous glomerulonephritis (1) } \\
\text { Unknown (2) }\end{array}$ & $\begin{array}{l}\text { SBP <5th } \\
\text { percentil } \\
\text { e for age } \\
\text { and } \\
\text { gender }\end{array}$ & $\begin{array}{l}\text { Sodiu } \\
\mathrm{m} \\
\text { profilin } \\
\text { g, UF } \\
\text { profilin } \\
\text { g and } \\
\text { mannit } \\
\text { ol }\end{array}$ & $\begin{array}{l}\text { Compared with the step } \\
\text { profile, the linear } \\
\text { profile increased the } \\
\text { odds of hypotensive } \\
\text { episodes or premature } \\
\text { discontinuation of } \\
\text { treatment by } 27 \% \\
\text { Compared to dialysis } \\
\text { treatments without } \\
\text { mannitol, the } \\
\text { administration of } \\
\text { mannitol reduced the } \\
\text { odds of intradialytic } \\
\text { symptoms by } 64 \% \\
\text { (p<0.05) but it did not } \\
\text { improve the odds of } \\
\text { preventing intradialytic } \\
\text { hypotension or } \\
\text { achieving ultrafiltration } \\
\text { volumes equal to the } \\
\text { interdialytic weight gain }\end{array}$ & $\begin{array}{l}\text { No difference in } \\
\text { UF profiling } \\
\text { versus constant } \\
\text { UF rate. Linear } \\
\text { sodium ramping } \\
\text { had increased } \\
\text { odds of } \\
\text { hypotensive } \\
\text { episodes or } \\
\text { premature } \\
\text { discontinuation } \\
\text { by } 27 \% \\
\text { compared to step } \\
\text { sodium ramping. } \\
\text { Step sodium } \\
\text { ramping better. }\end{array}$ \\
\hline $\begin{array}{l}\text { Fadel et al, } \\
2014 . \\
\text { Prospective, } \\
\text { observationa } \\
\text { 1, single } \\
\text { center study } \\
\text { over a period } \\
\text { of } 3 \text { months }\end{array}$ & 15 & $\begin{array}{l}11.4+/- \\
2.28 \\
\text { years }\end{array}$ & $\begin{array}{l}\text { Cystinosis and oxalosis (3) } \\
\text { Cystic kidney disease (1) } \\
\text { Vesicoureteric reflux, posterior } \\
\text { urethral valve or neurogenic bladder } \\
\text { (3) } \\
\text { Chronic interstitial nephritis (3) } \\
\text { Membranoproliferative }\end{array}$ & $\begin{array}{l}\text { Not } \\
\text { defined }\end{array}$ & $\begin{array}{l}\text { NIVM } \\
\text { using } \\
\text { CRIT- } \\
\text { LINE } \\
\text { III } \\
\text { TQA } \\
\text { monito } \\
\mathrm{r}\end{array}$ & $\begin{array}{l}\text { During phase } 3 \text { of the } \\
\text { study, a total of four } \\
\text { IME during } 180 \\
\text { treatment sessions } \\
\text { occurred compared } \\
\text { with } 33 \text { during phase } 1 \\
\text { (P = } 0.04 \text { ). Of the } 33 \\
\text { IME during phase } 1,25\end{array}$ & $\begin{array}{l}\text { Utilizing NIVM } \\
\text { to evaluate dry } \\
\text { weight resulted } \\
\text { in a significant } \\
\text { decrease in } \\
\text { frequency of } \\
\text { IME and }\end{array}$ \\
\hline
\end{tabular}




\begin{tabular}{|c|c|c|c|c|c|c|c|}
\hline & & & $\begin{array}{l}\text { glomerulonephritis (1) } \\
\text { Unknown (4) }\end{array}$ & & & $\begin{array}{l}\text { were associated with } \\
\text { hypotension compared } \\
\text { with two episodes of } \\
\text { hypotension associated } \\
\text { with the four IME } \\
\text { during phase } 3 \text { of the } \\
\text { study }(\mathrm{P}=0.01) .\end{array}$ & $\begin{array}{l}\text { associate } \\
\text { hypotension }\end{array}$ \\
\hline $\begin{array}{l}\text { Merouani et } \\
\text { al, } 2011 . \\
\text { Retrospectiv } \\
\text { e, single } \\
\text { center study } \\
\text { over a period } \\
\text { of } 7 \text { years }\end{array}$ & 23 & 11 years & $\begin{array}{l}\text { Tubular necrosis (8) } \\
\text { Hemolytic uremic syndrome (5) } \\
\text { Tumor lysis syndrome (3) } \\
\text { Drug toxicity (4) } \\
\text { Glomerulonephritis (1) } \\
\text { Other (2) }\end{array}$ & $\begin{array}{l}\text { SBP }<5 \text { th } \\
\text { percentil } \\
\text { e for age } \\
\text { and } \\
\text { gender }\end{array}$ & $\begin{array}{l}\text { Blood } \\
\text { volume } \\
\text { monito } \\
\text { ring }\end{array}$ & $\begin{array}{l}\text { The frequency of } \\
\text { hypotensive episodes } \\
\text { was similar between the } \\
\text { BVM group [33\%(95\% } \\
\text { CI: } 22 \%, 44 \%)] \text { and the } \\
\text { control group [36\% } \\
(95 \% \text { CI: } 24 \%, 48 \%)] \\
\text { but mean UF was } \\
\text { significantly higher in } \\
\text { the BVM group }(48+/- \\
27 \mathrm{~mL} / \mathrm{kg} \text { versus } 33+/- \\
26 \mathrm{~mL} / \mathrm{kg} ; \mathrm{P}<0.001)\end{array}$ & $\begin{array}{l}\text { No difference in } \\
\text { hypotension } \\
\text { episodes } \\
\text { occurred } \\
\text { between BVM } \\
\text { monitored and } \\
\text { unmonitored } \\
\text { groups, the UF } \\
\text { volume per } \\
\text { session was } \\
\text { higher in BVM } \\
\text { monitored } \\
\text { groups without } \\
\text { affecting } \\
\text { hypotensive } \\
\text { events }\end{array}$ \\
\hline $\begin{array}{l}\text { Hothi et al, } \\
2008 . \\
\text { Prospective, } \\
\text { observationa } \\
\text { 1, single } \\
\text { center study } \\
\text { over a period } \\
\text { of } 6 \text { months }\end{array}$ & 11 & $\begin{array}{l}12.8 \\
\text { years }\end{array}$ & $\begin{array}{l}\text { Focal segmental glomerulosclerosis } \\
\text { (1) } \\
\text { Autosomal recessive polycystic } \\
\text { kidney disease (1) } \\
\text { Renal dysplasia (4) } \\
\text { Chronic drug toxicity and BK virus } \\
\text { nephropathy secondary to cardiac } \\
\text { transplant (1) } \\
\text { Membranous glomerulonephritis (1) } \\
\text { ANCA negative glomerulonephritis } \\
\text { (1) } \\
\text { Unknown (2) }\end{array}$ & $\begin{array}{l}\text { SBP }<5 \text { th } \\
\text { percentil } \\
\text { e for age } \\
\text { and } \\
\text { gender }\end{array}$ & $\begin{array}{l}\text { NIVM } \\
\text { using } \\
\text { blood } \\
\text { volume } \\
\text { monito } \\
\mathrm{r}\end{array}$ & $\begin{array}{l}\text { Cut-off RBV thresholds } \\
\text { of } 88 \% \text { at the end of the } \\
\text { first hour, } 84 \% \text { at the } \\
\text { end of the second hour } \\
\text { and } 82 \% \text { at the end of } \\
\text { the third hour were the } \\
\text { best discriminators of } \\
\text { outcome, with a high } \\
\text { specificity and positive } \\
\text { predictive value (PPV) } \\
\text { for complicated } \\
\text { treatments but limited }\end{array}$ & $\begin{array}{l}\text { Positive } \\
\text { predictors of the } \\
\text { occurrence of } \\
\text { intradialytic } \\
\text { complications is } \\
\text { the changes in } \\
\text { the RBV curve } \\
\text { in the first hour } \\
\text { and intradialytic } \\
\text { heart rate }\end{array}$ \\
\hline
\end{tabular}




\begin{tabular}{|c|c|c|c|c|c|c|c|}
\hline & & & & & & $\begin{array}{l}\text { sensitivity and negative } \\
\text { predictive value (NPV). }\end{array}$ & \\
\hline $\begin{array}{l}\text { Blowey et al, } \\
1996 \\
\text { Case report }\end{array}$ & 1 & 18 years & Bardet-Biedl syndrome (1) & $\begin{array}{l}\text { Decrease } \\
\text { in mean } \\
\mathrm{BP} \text { by } 30 \\
\mathrm{mmHg}\end{array}$ & $\begin{array}{l}\text { Midodr } \\
\text { ine }\end{array}$ & $\begin{array}{l}\text { Blood pressure showed } \\
\text { a significant increase in } \\
\text { the average DBP during } \\
\text { midodrine therapy }(51.1 \\
+/-1.5 \mathrm{~mm} \mathrm{Hg} \mathrm{v} 38.0 \\
+/-1.5 \mathrm{~mm} \mathrm{Hg} ; \mathrm{P}< \\
0.05) \text { and an upward } \\
\text { trend in SBP }(85.7+/- \\
1.9 \mathrm{~mm} \mathrm{Hg} \mathrm{v} 79.8+/- \\
2.1 \mathrm{~mm} \mathrm{Hg} ; \mathrm{P}=0.2) .\end{array}$ & $\begin{array}{l}\text { Midodrine } \\
\text { successfully } \\
\text { increased } \\
\text { sympathetic } \\
\text { support during } \\
\text { HD sessions. } \\
\text { This resulted in } \\
\text { an increase in } \\
\text { BP and reduction } \\
\text { in resuscitative } \\
\text { interventions and } \\
\text { hypotensive } \\
\text { episodes }\end{array}$ \\
\hline $\begin{array}{l}\text { Hothi et al, } \\
2009 . \\
\text { Prospective } \\
\text { study, single } \\
\text { center study } \\
\text { over a period } \\
\text { of } 8 \text { months }\end{array}$ & 6 & $\begin{array}{l}12.3 \\
\text { years }\end{array}$ & $\begin{array}{l}\text { Membranous glomerulonephritis (1) } \\
\text { ANCA-positive glomerulonephritis } \\
\text { (1) } \\
\text { Nephronophthsis (1) } \\
\text { Hypocomplementemic } \\
\text { glomerulonephritis (1) } \\
\text { Autosomal recessive polycystic } \\
\text { kidney disease (1) } \\
\text { Solitary ectopic dysplastic kidney (1) }\end{array}$ & $\begin{array}{l}\text { SBP <5th } \\
\text { percentil } \\
\text { e for age } \\
\text { and } \\
\text { gender }\end{array}$ & $\begin{array}{l}\text { Mannit } \\
\text { ol, } \\
\text { midodr } \\
\text { ine \& } \\
\text { sequent } \\
\text { ial } \\
\text { dialysis }\end{array}$ & $\begin{array}{l}\text { During } 18 \text { of } 20 \\
\text { observed dialysis } \\
\text { sessions, a } 2.5 \mathrm{mg} \text { oral } \\
\text { dose of midodrine } \\
\text { produced a } 10 \text { - to } 15- \\
\text { mmHg increase in the } \\
\text { systolic BP within } 30 \\
\text { min of administration, } \\
\text { and no adverse effects }\end{array}$ & $\begin{array}{l}\text { Intradialytic } \\
\text { mannitol and } \\
\text { sequential } \\
\text { dialysis } \\
\text { decreased odds } \\
\text { of intradialytic } \\
\text { symptoms, } \\
\text { hypotension, and } \\
\text { premature } \\
\text { discontinuation } \\
\text { of dialysis by } \\
\text { half } \\
\text { Intradialytic } \\
\text { mannitol and } \\
\text { midodrine } \\
\text { increased mean } \\
\text { treatment UF } \\
\text { volume } \\
\text { Intradialytic } \\
\text { midodrine }\end{array}$ \\
\hline
\end{tabular}




\begin{tabular}{|c|c|c|c|c|c|c|c|}
\hline & & & & & & & $\begin{array}{l}\text { caused no } \\
\text { significant } \\
\text { intradialytic } \\
\text { symptoms }\end{array}$ \\
\hline $\begin{array}{l}\text { Brooks et al, } \\
2008 . \\
\text { Randomized } \\
\text { single- } \\
\text { blinded, } \\
\text { single center } \\
\text { study over a } \\
\text { period of } 2 \\
\text { weeks }\end{array}$ & 7 & $\begin{array}{l}13.3+/- \\
2.1 \\
\text { years }\end{array}$ & $\begin{array}{l}\text { Membranoproliferative } \\
\text { glomerulonephritis type } 1(1) \\
\text { Unknown etiology, end stage renal } \\
\text { disease (1) } \\
\text { Renal dysplasia (1) } \\
\text { Obstructive uropathy (2) } \\
\text { Reflux nephropathy (1) } \\
\text { Focal segmental glomerulosclerosis } \\
\text { (1) }\end{array}$ & $\begin{array}{l}\text { Not } \\
\text { defined }\end{array}$ & $\begin{array}{l}\text { Bioelec } \\
\text { trical } \\
\text { Impeda } \\
\text { nce }\end{array}$ & $\begin{array}{l}\text { Showed significant } \\
\text { differences in total body } \\
\text { water, between pre-HD } \\
\text { and hours } 2 \text { and } 3 \text {, and } \\
\text { post-HD but not } \\
\text { between pre-HD and } \\
\text { hour } 1 \text {. Study avoided } \\
\text { precipitous drop in } \\
\text { blood volume early in } \\
\text { the HD session to avoid } \\
\text { a drop in patients' blood } \\
\text { pressures. }\end{array}$ & $\begin{array}{l}\text { BIA has a strong } \\
\text { relation with } \\
\text { change in TBW, } \\
\text { UF loss, } \\
\text { impedance } \\
\text { vector evaluating } \\
\text { tissue hydration, } \\
\text { blood pressure, } \\
\text { and heart rate. } \\
\text { Thus, using BIA } \\
\text { during HD } \\
\text { treatment is a } \\
\text { good predictor of } \\
\text { intravascular } \\
\text { hypovolemia and } \\
\text { hypotensive } \\
\text { episodes before } \\
\text { symptoms arise. }\end{array}$ \\
\hline $\begin{array}{l}\text { Hegazy et al, } \\
2011 . \\
\text { Cross over, } \\
\text { single center } \\
\text { study over a } \\
\text { period of } 6 \\
\text { months }\end{array}$ & 28 & $\begin{array}{l}9.9+/- \\
3.1 \\
\text { years }\end{array}$ & End stage renal disease (28) & $\begin{array}{l}\text { Not } \\
\text { defined }\end{array}$ & $\begin{array}{l}\text { Coolin } \\
\text { g } \\
\text { Dialysa } \\
\text { te }\end{array}$ & $\begin{array}{l}\text { Patients with cold } \\
\text { dialysate had less } \\
\text { number of hypotensive } \\
\text { episodes }(2.09 \pm 1.87) \text { as } \\
\text { compared to warm } \\
\text { dialysis }(8.18 \pm 3.06) \mathrm{p}= \\
0.0001\end{array}$ & $\begin{array}{l}\text { The use of } \\
\text { cooled dialysate } \\
\left(35^{\circ} \mathrm{C}\right) \text { reduced } \\
\text { frequency of } \\
\text { hypotensive } \\
\text { episodes and } \\
\text { reduction of } \\
\text { basal heart } \\
\text { rate/blood } \\
\text { pressure by } \\
\text { improving heart } \\
\text { rate variability } \\
\text { parameters } \\
\text { compared to }\end{array}$ \\
\hline
\end{tabular}




\begin{tabular}{|c|c|c|c|c|c|c|c|}
\hline & & & & & & & $\begin{array}{l}\text { warm dialysate } \\
\text { temperature } \\
\left(37^{\circ} \mathrm{C}\right) .\end{array}$ \\
\hline $\begin{array}{l}\text { Levtchenko } \\
\text { et al, } 2003 . \\
\text { Prospective } \\
\text { study }\end{array}$ & 16 & $\begin{array}{l}3-17 \\
\text { years } \\
\text { old }\end{array}$ & Not defined & $\begin{array}{l}\text { Not } \\
\text { defined }\end{array}$ & $\begin{array}{l}\text { NIVM } \\
\text { using } \\
\text { Crit } \\
\text { line, } \\
\text { Hema } \\
\text { Metrics }\end{array}$ & $\begin{array}{l}\text { Changes in blood } \\
\text { volume significantly } \\
\text { correlated with the } \\
\text { changes of patient's } \\
\text { weight during } \\
\text { hemodialysis treatments } \\
\text { (p } 1 / 40.001 \text { ) }\end{array}$ & $\begin{array}{l}\text { Non-invasive } \\
\text { monitoring of } \\
\text { hematocrit is } \\
\text { beneficial in } \\
\text { estimating dry } \\
\text { weight in } \\
\text { children and can } \\
\text { monitor and } \\
\text { prevent } \\
\text { intradialytic side } \\
\text { effects. }\end{array}$ \\
\hline $\begin{array}{l}\text { Goldstein et } \\
\text { al, } 2008 \text {. } \\
\text { Prospective, } \\
\text { two center, } \\
\text { study over a } \\
\text { period of } 16 \\
\text { weeks }\end{array}$ & 4 & $\begin{array}{l}\text { Not } \\
\text { defined }\end{array}$ & End stage renal disease (4) & $\begin{array}{l}\text { Not } \\
\text { defined }\end{array}$ & $\begin{array}{l}\text { Quotidi } \\
\text { an } \\
\text { hemodi } \\
\text { alysis }\end{array}$ & $\begin{array}{l}\text { Review of ABPM data } \\
\text { demonstrated } \\
\text { improvement in both } \\
\text { 24-h predialysis- } \\
\text { treatment systolic and } \\
\text { diastolic BPs and BP } \\
\text { loads between the pre- } \\
\text { and 4-month end-of- } \\
\text { study }\end{array}$ & $\begin{array}{l}\text { Performing } \\
\text { dialysis } \\
\text { frequently } \\
\text { throughout the } \\
\text { week with } \\
\text { shorter duration } \\
\text { resulted in } \\
\text { improvement of } \\
\text { intradialytic } \\
\text { symptoms and } \\
\text { BP } \\
\text { measurements }\end{array}$ \\
\hline $\begin{array}{l}\text { Jain et al, } \\
2001 . \\
\text { Retrospectiv } \\
\text { e cohort, } \\
\text { single center } \\
\text { study over a } \\
\text { period of } 1 \\
\text { month }\end{array}$ & 24 & $\begin{array}{l}12.28 \\
+/-5.98 \\
\text { years }\end{array}$ & $\begin{array}{l}\text { Focal segmental glomerular sclerosis } \\
(n=3) \\
\text { Posterior urethral valves }(n=1) \\
\text { Renal dysplasia }(n=2) \\
\text { Cortical necrosis }(n=1) \\
\text { Sickle cell nephropathy }(n=1) \\
\text { Angiotensin converting enzyme }\end{array}$ & $\begin{array}{l}\text { Not } \\
\text { defined }\end{array}$ & $\begin{array}{l}\text { Biofee } \\
\text { dback }\end{array}$ & $\begin{array}{l}\text { For patients }<35 \mathrm{~kg} \text {, the } \\
\text { event rate was } \\
\text { significantly lower } \\
\text { when NIVM was } \\
\text { performed (no } \\
\text { NIVM=38/80, } \\
\text { NIVM }=25 / 100, P=0.01 \text { ) }\end{array}$ & $\begin{array}{l}\text { Biofeedback } \\
\text { technology was } \\
\text { able to improve } \\
\text { intradialytic } \\
\text { symptoms. } \\
\text { Additionally, } \\
\text { without affecting } \\
\text { dry weight } \\
\text { estimations, }\end{array}$ \\
\hline
\end{tabular}




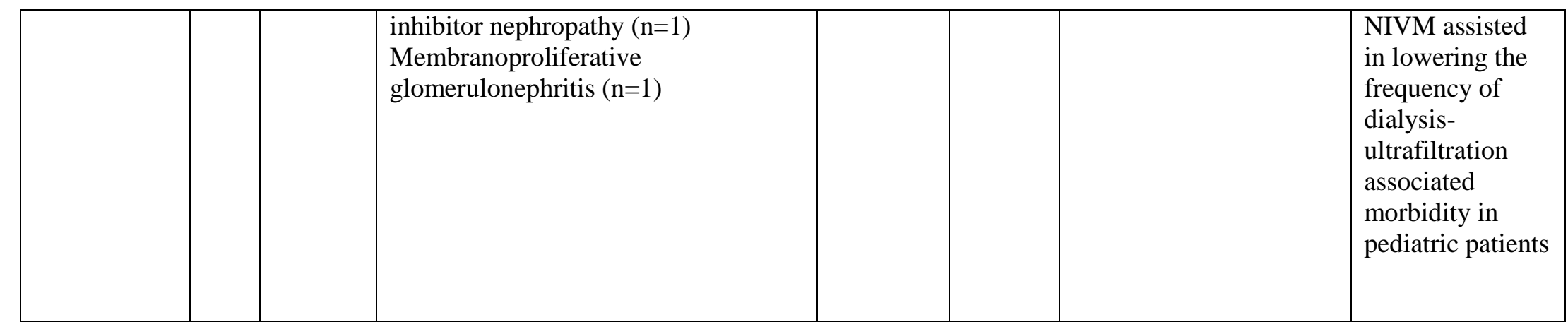

SBP - systolic blood pressure, UF - Ultrafiltration, NIVM - non-invasive hematocrit monitoring, IME - intradialytic morbid events, BVM - blood volume monitoring, RBV - relative blood volume, HD - hemodialysis, BP - blood pressure, BIA - bioelectrical impedance, TBW - total body water, DBP - diastolic blood pressure, SBP - systolic blood pressure 
Table 2: Hemodialysis Parameters

\begin{tabular}{|c|c|c|c|c|c|}
\hline Study & Dialyzer type & Dialyzer membrane & Dialysate solution & $\begin{array}{l}\text { Dialysate } \\
\text { temperature }\end{array}$ & $\begin{array}{l}\text { Session } \\
\text { duration }\end{array}$ \\
\hline $\begin{array}{l}\text { Fadel et al, 2014, } \\
\text { prospective study }\end{array}$ & Fresenius 4008B & Low flux & Bicarbonate based & $36^{0} \mathrm{C}$ & $4 \mathrm{~h}, 3 \mathrm{x} /$ week \\
\hline $\begin{array}{l}\text { Merouani et al, } \\
2011, \\
\text { retrospective study }\end{array}$ & Fresenius $2008 \mathrm{~K}$ & Biocompatible based & Bicarbonate based & $37^{0} \mathrm{C}$ & Varies \\
\hline $\begin{array}{l}\text { Hothi et al, } 2008, \\
\text { retrospective study }\end{array}$ & $\begin{array}{l}\text { Fresenius } 2008 \mathrm{~K} \\
\text { or } 2008 \mathrm{H}\end{array}$ & $\begin{array}{l}\text { High-flux triacetate } \\
\text { cellulose or polysulfone } \\
\text { membranes }\end{array}$ & $\begin{array}{l}\text { Dialyzed against } 35 \mathrm{mmol} / 1 \\
\text { bicarbonate, profiles of } \\
145-148 \mathrm{mmol} / \mathrm{l} \text { at the } \\
\text { onset, falling to } 135-138 \\
\mathrm{mmol} / 1 \text { in a step-wise } \\
\text { manner. }\end{array}$ & $37.5^{0} \mathrm{C}$ & $\begin{array}{l}3 \mathrm{~h}, 4 \mathrm{x} / \text { week } \\
\text { or } 4 \mathrm{~h}, \\
3 \mathrm{x} / \text { week }\end{array}$ \\
\hline $\begin{array}{l}\text { Hothi et al, } 2009 \text {, } \\
\text { prospective study }\end{array}$ & $\begin{array}{l}\text { Fresenius } 2008 \mathrm{~K} \\
\text { or } 2008 \mathrm{H}\end{array}$ & Not defined & Bicarbonate based & Not defined & $3 \mathrm{~h} 3 \mathrm{x} /$ week \\
\hline $\begin{array}{l}\text { Brooks et al, } \\
2008, \text { randomized } \\
\text { study }\end{array}$ & $\begin{array}{l}\text { Fresenius } \\
\text { Hemoflow } \\
\text { Polysulfone } \\
\text { Hollow Fiber } \\
\text { Filters (F4 to F8) }\end{array}$ & Not defined & Not defined & Not defined & 3.5-4 hours \\
\hline $\begin{array}{l}\text { Hegazy et al, } \\
2011, \text { cross } \\
\text { sectional study }\end{array}$ & Not defined & Not defined & Not defined & $\begin{array}{l}3 \text { months of } 37^{0} \mathrm{C} \\
\text { then } 3 \text { months of } \\
35^{0} \mathrm{C}\end{array}$ & Not defined \\
\hline
\end{tabular}




\begin{tabular}{|l|l|l|l|l|l|}
\hline $\begin{array}{l}\text { Levtchenko et al, } \\
\text { 2003, prospective } \\
\text { study }\end{array}$ & Not defined & Not defined & Not defined & Not defined & Not defined \\
\hline $\begin{array}{l}\text { Goldstein et al, } \\
\text { 2008, prospective } \\
\text { study }\end{array}$ & $\begin{array}{l}\text { NxStage System } \\
\text { One }\end{array}$ & Not defined & Not defined & $\begin{array}{l}\text { Not defined } \\
(\mathrm{mean} \text { time }) \\
6 \mathrm{x} / \mathrm{week}\end{array}$ \\
\hline $\begin{array}{l}\text { Jaine et al, 2001, } \\
\text { prospective study }\end{array}$ & Not defined & Not defined & $\begin{array}{l}\text { Sodium } 140 \mathrm{mmol} / \mathrm{l}, \\
\text { Potassium } 2 \mathrm{mmol} / \mathrm{l}, \\
\text { Calcium } 3 \mathrm{mmol} / \mathrm{l}, \text { and } \\
\text { Bicarbonate } 35 \mathrm{mmol} / \mathrm{l}\end{array}$ & Not defined & $3-4$ hours \\
\hline
\end{tabular}


Table 3. Summary of hemodiafiltration and hemofiltration studies for prevention of intradialytic hypotension

* Mixed adult \& pediatric patients

IDH - intradialytic hypotension, NA - not available, HD - hemodialysis, HDF - hemodiafiltration, HF - hemofiltration, BVM - blood volume monitor, $\mathrm{BV}$ - blood volume, $\mathrm{RBV}$ relative blood volume, $\mathrm{Na}$ - sodium, $\mathrm{K}$ - potassium, $\mathrm{Cl}$ - chloride, $\mathrm{Ca}-\mathrm{calcium}, \mathrm{Mg}-$ magnesium, LMWH - low molecular weight heparin, HUS - hemolytic uremic syndrome, CsA - cyclosporine, ARPKD - adult polycystic kidney disease, ESRD - end stage renal disease, GN - glomerulonephritis, PD - peritoneal dialysis.

\begin{tabular}{|c|c|c|c|c|c|c|c|c|}
\hline Study & $\mathbf{N}$ & Age & $\begin{array}{l}\text { Indications } \\
\text { (number of } \\
\text { patients) }\end{array}$ & $\begin{array}{l}\text { Defini } \\
\text { tion } \\
\text { of } \\
\text { IDH }\end{array}$ & Intervention Used & Dialysis characteristics & $\begin{array}{l}\text { Mor } \\
\text { talit } \\
\mathbf{y}\end{array}$ & $\begin{array}{l}\text { Outcome \& } \\
\text { Recommendation }\end{array}$ \\
\hline $\begin{array}{l}\text { Dheu et al, } \\
2008 \\
\text { Retrospecti } \\
\text { ve study }\end{array}$ & 14 & $\begin{array}{l}8-9 \\
\text { years } \\
\text { at the } \\
\text { begin } \\
\text { ning } \\
\text { of the } \\
\text { study }\end{array}$ & $\begin{array}{l}\text { Malformative } \\
\text { uropathy (4) } \\
\text { Bardet Biedl } \\
\text { syndrome (2) } \\
\text { Renal } \\
\text { hypoplasia } \\
\text { (3) } \\
\text { Corticoresista } \\
\text { nt nephrotic } \\
\text { syndrome (2) } \\
\text { Nephronophti } \\
\text { sis (1) } \\
\text { Nail Patella } \\
\text { syndrome (1) } \\
\text { Bilateral } \\
\text { Wilms } \\
\text { tumor(1) }\end{array}$ & NA & $\begin{array}{l}\text { HDF for } 4 \text { years } \\
\text { with special focus on } \\
\text { the shape of BVM } \\
\text { curves to predict } \\
\text { changes in body } \\
\text { fluid status. }\end{array}$ & $\begin{array}{l}\text { Online-HDF using Fresenius A } 4008 \\
\text { machines, } 3-4 \text { hours per session and } 3-5 \\
\text { times/week } \\
\text { Bicarbonate buffer dialysate }-\mathrm{Na} 140 \\
\text { mmol/L, } \mathrm{K} 2 \mathrm{mmol} / \mathrm{L}, \mathrm{Ca} 1.5 \mathrm{mmol} / \mathrm{L}, \mathrm{Mg} \\
0.5 \mathrm{mmol} / \mathrm{L} \text {, bicarbonate } 34 \mathrm{mmol} / \mathrm{L} \text {, } \\
\text { glucose } 1 \mathrm{~g} / \mathrm{L} \& \text { temperature } 37^{0} \mathrm{C} \text {. High- } \\
\text { flux polysulfone hollow-fiber dialyzer, } \\
\text { replacement fluid was ultrapure dialysate } \\
\text { infused pre-filter at } 2 / 3^{\text {rd }} \text { the blood flow } \\
\text { rate \& anticoagulation with LMWH. Blood } \\
\text { flow rate } 150 \mathrm{~mL} / \mathrm{min} / \mathrm{m}^{2} \& \text { dialysate flow } \\
\text { rate } 500-800 \mathrm{ml} / \mathrm{min} \text {. Prescription adjusted } \\
\text { to attain a Kt/V urea of } 1.4 \text { (on-line } \\
\text { assessment). Safety of the procedure was } \\
\text { established with loss of body weight } \\
\text { limited to } 1.5 \pm 0.5 \% \text { / hour and BV changes } \\
\text { limited to }<8 \% \text { in the first hour and <4\% } \\
\text { thereafter. }\end{array}$ & & $\begin{array}{l}\text { Total of } 2240 \text { BVM } \\
\text { curve shapes during } 4 \\
\text { year period were } \\
\text { analyzed. In } 91 \% \text { of } \\
\text { sessions, normal } \\
\text { curve shapes were } \\
\text { observed (initial rapid } \\
\text { fall of BV <8\% in the } \\
\text { first hour followed by } \\
\text { progressive } \\
\text { attainment of a } \\
\text { plateau not less than a } \\
12 \% \text { RBV decrease). } \\
\text { In 5\% of the sessions, } \\
\text { initial decrease of BV } \\
\text { was not seen and can } \\
\text { indicate the risk of } \\
\text { fluid overload. In } 4 \% \\
\text { of the sessions, initial } \\
\text { BV fall was }>8 \% \\
\text { without reaching a }\end{array}$ \\
\hline
\end{tabular}




\begin{tabular}{|c|c|c|c|c|c|c|c|c|}
\hline & & & & & & & & $\begin{array}{l}\text { stable plateau, which } \\
\text { indicates the risk of } \\
\text { hypotension. Less } \\
\text { than } 2 \% \text { of the } \\
\text { sessions ( } 44 \text { sessions) } \\
\text { witnessed } \\
\text { intradialytic } \\
\text { symptoms including } \\
\text { IDH that was not } \\
\text { predicted by BVM. }\end{array}$ \\
\hline $\begin{array}{l}\text { Thumfart et } \\
\text { al, } 2014 \\
\text { Prosepctive } \\
\text { observation } \\
\text { al crossover } \\
\text { study }\end{array}$ & 7 & $\begin{array}{l}13.4- \\
16.3 \\
\text { years }\end{array}$ & $\begin{array}{l}\text { HUS (1) } \\
\text { Interstitial } \\
\text { nephritis (1) } \\
\text { CsA toxicity } \\
\text { after heart } \\
\text { transplantatio } \\
\text { n (1) } \\
\text { Alport's } \\
\text { Syndrome (1) } \\
\text { Wegener's } \\
\text { granulomatos } \\
\text { is (1) } \\
\text { Urethral } \\
\text { valves (1) } \\
\text { ARPKD (1) }\end{array}$ & $\begin{array}{l}\text { Deter } \\
\text { mined } \\
\text { as the } \\
\text { need } \\
\text { for } \\
\text { fluid } \\
\text { bolus }\end{array}$ & $\begin{array}{l}\text { Conventional HD for } \\
3 \text { months initially, } \\
\text { then } 3 \text { months of } \\
\text { nocturnal HD } \\
\text { followed by } 3 \\
\text { months of nocturnal } \\
\text { online-HDF and then } \\
\text { back to nocturnal } \\
\text { HD }\end{array}$ & $\begin{array}{l}\text { Fresenius } 4008 \mathrm{H} \& 5008 \mathrm{H} \text { machines with } \\
\text { online ultrapure substitution fluid and } \\
\text { heparin anticoagulation were used. The } \\
\text { dialysate composition }(\mathrm{Na}, \mathrm{K} \& \\
\text { bicarbonate) was set after initial electrolyte } \\
\text { determination \& Ca was set at } 1.75 \\
\mathrm{mmol} / \mathrm{l} \text {. Blood flow rate } 4-6 \mathrm{ml} / \mathrm{min} / \mathrm{kg} \\
\text { body weight, dialysate flow rate } 500 \\
\mathrm{ml} / \mathrm{min} \& \text { convective flow at } 1 / 3^{\text {rd }} \text { the } \\
\text { blood flow rate in post-dilution mode. }\end{array}$ & & $\begin{array}{l}\text { IDH events were } \\
\text { lower during } \\
\text { nocturnal HD and } \\
\text { nocturnal HDF } \\
\text { compared to } \\
\text { conventional HD }\end{array}$ \\
\hline $\begin{array}{l}\text { Zarauza- } \\
\text { Santovena } \\
\text { et al, 2015 } \\
\text { Single- } \\
\text { centre, } \\
\text { observation } \\
\text { al, }\end{array}$ & 7 & $\begin{array}{l}2.4-14 \\
\text { years }\end{array}$ & $\begin{array}{l}\text { Structural } \\
\text { disease (1) } \\
\text { Glomerular } \\
\text { disease (1) } \\
\text { Hereditary } \\
\text { disease (4) } \\
\text { Graft loss (1) }\end{array}$ & NA & $\begin{array}{l}\text { Patients on chronic } \\
\text { HD ( }>3 \text { months) } \\
\text { who had online-HDF } \\
\text { for }>1 \text { month } \\
\text { included in the } \\
\text { study. Duration of } \\
\text { online-HDF ranged }\end{array}$ & Fresenius 4008 \& 5008 machines used & 0 & $\begin{array}{l}\text { Fewer episodes of } \\
\text { hypotension among } \\
\text { patients on online- } \\
\text { HDF }(0.21 \\
\text { episodes/patient/week } \\
\text { vs } 0.58 ; \mathrm{p}=0.028) \text {. } \\
\text { Higher clearance of }\end{array}$ \\
\hline
\end{tabular}




\begin{tabular}{|c|c|c|c|c|c|c|c|c|}
\hline $\begin{array}{l}\text { retrospectiv } \\
\text { e study }\end{array}$ & & & & & $\begin{array}{l}\text { between } 1.5-12 \\
\text { months }\end{array}$ & & & $\begin{array}{l}\text { beta } 2 \text {-microglobuline } \\
\text { was observed with } \\
\text { online-HDF } \\
\text { (reduction ratio per } \\
\text { session } 79.4 \% \text { vs } \\
66.7 \%, \mathrm{p}=0.018 \text { ), with } \\
\text { the same urea } \\
\text { reduction ratio } \\
(79.1 \%) \text { and Kt/V } \\
(1.66 \mathrm{vs} 1.65) .\end{array}$ \\
\hline $\begin{array}{l}\text { Fischbach } \\
\text { et al, } 2004 \\
\text { Single- } \\
\text { center, } \\
\text { observation } \\
\text { al, } \\
\text { prospective } \\
\text { and non- } \\
\text { randomized } \\
\text { study }\end{array}$ & 5 & $\begin{array}{l}13.8 \pm \\
3.2 \\
\text { years }\end{array}$ & $\begin{array}{l}\text { Bilateral } \\
\text { Wilms' } \\
\text { tumor (1) } \\
\text { Posterior } \\
\text { urethral valve } \\
(2) \\
\text { Bardet Biedl } \\
\text { syndrome (1) } \\
\text { Henoch- } \\
\text { Schoenlein } \\
\text { syndrome (1) }\end{array}$ & NA & $\begin{array}{l}\text { Standard online- } \\
\text { HDF for at least six } \\
\text { months ( } 4 \text { hrs, } 3 \\
\text { times/week) } \\
\text { followed by } \\
\text { daily online-HDF ( } 3 \\
\text { hrs, } 6 \text { times/week) }\end{array}$ & $\begin{array}{l}\text { Same hemodialysis configuration for both } \\
\text { standard and daily online-HDF. Fresenius } \\
4008 \text {, FX } 6 \text { polysulphone dialyzer, blood } \\
\text { flow } 180 \pm 50 \mathrm{ml} / \mathrm{min} \text {, dialysate flow } 500 \\
\mathrm{ml} / \mathrm{min} \text {, predilution mode with reinfusion } \\
\text { flow limited to } 200 \mathrm{ml} / \mathrm{min} \text {. }\end{array}$ & 0 & $\begin{array}{l}\text { Compared to standard } \\
\text { online-HDF, daily } \\
\text { online-HDF was well } \\
\text { tolerated without any } \\
\text { dialysis related } \\
\text { complications and } \\
\text { with good blood } \\
\text { pressure control. With } \\
\text { daily online-HDF, } \\
\text { increased dialysis } \\
\text { dose was achieved in } \\
\text { addition to significant } \\
\text { regression in LV } \\
\text { hypertrophy and } \\
\text { improvement in LV } \\
\text { systolic function. }\end{array}$ \\
\hline $\begin{array}{l}\text { *Baldamus } \\
\text { et al, 1978, } \\
\text { Crossover } \\
\text { study }\end{array}$ & 6 & $\begin{array}{l}17-63 \\
\text { years }\end{array}$ & $\begin{array}{l}\text { ESRD } \\
\text { patients, } \\
\text { causes not } \\
\text { reported }\end{array}$ & NA & $\begin{array}{l}2 \text { months of HD } \\
\text { (control period), then } \\
4 \text { months of HF } \\
\text { followed by } 2 \\
\text { months of HD for } \\
\text { subjects who } \\
\text { withdrew HF }\end{array}$ & $\begin{array}{l}\text { HD }-6 \text { hour sessions thrice weekly, } \\
\text { Gambro Optima dialyzer, blood flow } 200 \text { - } \\
300 \mathrm{ml} / \mathrm{min} \text {, dialysate flow } 500 \mathrm{ml} / \mathrm{min} \text {. } \\
\text { Dialysate composed of } 136 \mathrm{mEq} / \mathrm{l} \mathrm{Na}, 2.5 \\
\mathrm{mEq} / \mathrm{l} \mathrm{K}, 3.8 \mathrm{mEq} / \mathrm{l} \mathrm{Ca}, 1.2 \mathrm{mEq} / 1 \mathrm{Mg}, 34 \\
\mathrm{mEq} / \mathrm{l} \text { acetate, } 1.5 \mathrm{mEq} / \mathrm{L} \text { lactate, } 108 \\
\mathrm{mEq} / \mathrm{l} \mathrm{Cl} \mathrm{\&} 140 \mathrm{mg} / 100 \mathrm{ml} \text { glucose. }\end{array}$ & 0 & $\begin{array}{l}\text { IDH events were less } \\
\text { frequent during HF. } \\
\text { This study concluded } \\
\text { that HF was superior } \\
\text { to HD in patients with } \\
\text { frequent IDH }\end{array}$ \\
\hline
\end{tabular}




\begin{tabular}{|c|c|c|c|c|c|c|c|c|}
\hline & & & & & & $\begin{array}{l}\mathrm{HF}-20 \mathrm{~L} \text { infusate/session thrice weekly, } \\
\mathrm{UF} \text { rate } 60-70 \mathrm{ml} / \mathrm{min} \text {, polyacrylonitrile } \\
\text { membrane dialyzer \& asymmetric } \\
\text { cellulose acetate membrane filter, blood } \\
\text { flow } 200-300 \mathrm{ml} / \mathrm{min} \text {, replacement fluid } \\
\text { composition was same as dialysate except } \\
\text { for } 138 \mathrm{mEq} / \mathrm{L} \mathrm{Na} \& 35 \mathrm{mEq} / \mathrm{L} \text { of lactate } \\
\text { instead of acetate. }\end{array}$ & & $\begin{array}{l}\text { episodes and fluid } \\
\text { removal issues. }\end{array}$ \\
\hline $\begin{array}{l}\text { *Quellhorst } \\
\text { et al, } 1983\end{array}$ & 72 & $\begin{array}{l}\text { 12-16 } \\
\text { years } \\
\text { (4 } \\
\text { patien } \\
\text { ts) } \\
34-78 \\
\text { years } \\
\text { (remai } \\
\text { ning } \\
\text { patien } \\
\text { ts) }\end{array}$ & $\begin{array}{l}\text { Chronic GN } \\
\text { (34) } \\
\text { Chronic } \\
\text { pyelonephriti } \\
\text { s (22) } \\
\text { Nephrosclero } \\
\text { sis (8) } \\
\text { Diabetic } \\
\text { nephropathy } \\
\text { (8) }\end{array}$ & NA & $\begin{array}{l}\text { Post-dilution HF for } \\
>6 \text { months, HD \& } \\
\text { continuous } \\
\text { ambulatory PD }\end{array}$ & $\begin{array}{l}\text { Three times/week, } 20-30 \mathrm{~L} \text { of fluid } \\
\text { exchanged/session. Sartorius, Gambro or } \\
\text { Amicon filters were used. Composition of } \\
\text { substitution fluid was Na } 142 \mathrm{mmol} / \mathrm{L}, \mathrm{K} 2 \\
\mathrm{mmol} / \mathrm{L}, \mathrm{Ca} 2 \mathrm{mmol} / \mathrm{L}, \mathrm{Mg} 0.75 \mathrm{mmol} / \mathrm{L} \text {, } \\
\mathrm{Cl} 105 \mathrm{mmol} / \mathrm{L} \& \text { lactate } 44.5 \mathrm{mmol} / \mathrm{l} \text {. }\end{array}$ & $\begin{array}{l}12 \\
\text { (enc } \\
\text { epha } \\
\text { loma } \\
\text { lacia } \\
\text {, } \\
\text { cere } \\
\text { bral } \\
\text { hem } \\
\text { orrh } \\
\text { age } \\
\& \\
\text { cardi } \\
\text { ac } \\
\text { infar } \\
\text { ction } \\
\text { ) }\end{array}$ & $\begin{array}{l}\text { Main reason for } \\
\text { transfer from HD to } \\
\text { HF were hypotension, } \\
\text { hypertension and/or } \\
\text { repeated } \\
\text { overhydration events. }\end{array}$ \\
\hline
\end{tabular}


Table 4. Summary of consensus panel recommendations and their strengths \& evidence level.

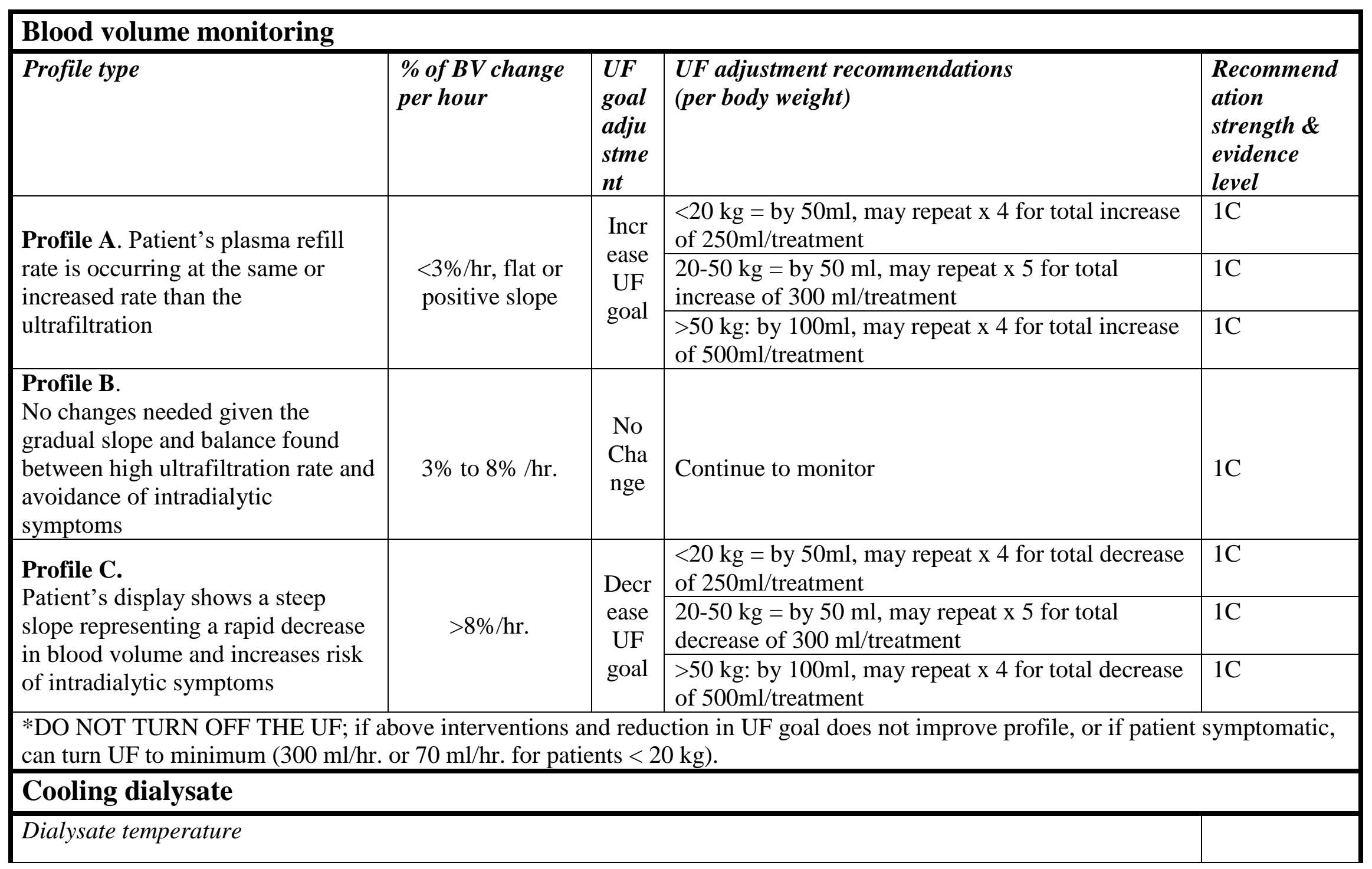




\begin{tabular}{|c|c|c|c|}
\hline \multicolumn{3}{|l|}{$35^{0} \mathrm{C}$} & $2 \mathrm{C}$ \\
\hline \multicolumn{3}{|l|}{$36^{0} \mathrm{C}$} & $2 \mathrm{C}$ \\
\hline \multicolumn{3}{|l|}{$37.5^{0} \mathrm{C}$} & $2 \mathrm{C}$ \\
\hline \multicolumn{4}{|c|}{ Sodium profiling } \\
\hline \multicolumn{2}{|c|}{ Type of profile } & Dialysate sodium levels & \\
\hline \multicolumn{2}{|c|}{$\begin{array}{l}\text { Linear sodium profiling: Steady decline of dialysate } \\
\text { sodium concentration throughout the hemodialysis } \\
\text { treatment until the final sodium concentration is } \\
\text { achieved }\end{array}$} & $\begin{array}{l}148 \mathrm{mmol} / \mathrm{l} \text { at the initiation of dialysis and } 138 \mathrm{mmol} / \mathrm{l} \text { at } \\
\text { end of dialysis }\end{array}$ & $3 \mathrm{C}$ \\
\hline \multicolumn{2}{|c|}{$\begin{array}{l}\text { Step sodium profiling: The initial sodium } \\
\text { concentration remains constant until } 30 \text { minutes prior to } \\
\text { the end of hemodialysis and then the concentration of } \\
\text { sodium decreased to a final level of } 138 \mathrm{mmol} / \mathrm{L}\end{array}$} & $\begin{array}{l}\text { Initial sodium concentration of } 148 \mathrm{mmol} / \mathrm{l} \text { is maintained } \\
\text { until } 30 \mathrm{~min} \text { before the end of dialysis session, then drops } \\
\text { to final sodium concentration of } 138 \mathrm{mmol} / \mathrm{l}\end{array}$ & $3 \mathrm{C}$ \\
\hline Mannitol & \multicolumn{2}{|c|}{$1 \mathrm{~g} / \mathrm{kg}$ during the first hour of first dialysis session of the week or $0.5 \mathrm{~g} / \mathrm{kg}$ two times $/$ week } & 3D \\
\hline \multicolumn{3}{|c|}{ Bioelectric impedance } & 4D \\
\hline \multicolumn{3}{|c|}{ Ultrafiltration profiling } & 4D \\
\hline \multicolumn{3}{|c|}{ Sequential dialysis } & $3 \mathrm{D}$ \\
\hline \multicolumn{3}{|c|}{ Biofeedback } & $3 \mathrm{C}$ \\
\hline \multicolumn{3}{|c|}{ Quotidian hemodialysis } & $4 \mathrm{D}$ \\
\hline \multicolumn{3}{|c|}{ Body surface area based UF rate adjustment } & $4 \mathrm{D}$ \\
\hline \multicolumn{3}{|c|}{ Hemodiafiltration } & $2 \mathrm{C}$ \\
\hline \multicolumn{3}{|c|}{ Hemofiltration } & $4 \mathrm{D}$ \\
\hline
\end{tabular}

$\mathrm{BV}$ - blood volume, UF - ultrafiltration, $\mathrm{BP}$ - blood pressure, SBP - systolic blood pressure 
Table 5. Types of sodium profiles [19]

\begin{tabular}{|l|l|l|l|}
\hline & Decreasing Profile & Increasing Profile & Alternating Profile \\
\hline $\begin{array}{l}\text { Profile } \\
\text { Description }\end{array}$ & $\begin{array}{l}\text { During treatment, } \\
\text { sodium concentration } \\
\text { is decreased } \\
\text { proportionally with } \\
\text { dialysate dilution to } \\
\text { isosmolar levels }\end{array}$ & $\begin{array}{l}\text { The plasma volume is } \\
\text { preserved towards the } \\
\text { end of dialysis where } \\
\text { ultrafiltration remains } \\
\text { high }\end{array}$ & $\begin{array}{l}\text { Hypernatric and hyponatric } \\
\text { dialysate is introduced that } \\
\text { causes alternating fluid shift } \\
\text { across the cellular } \\
\text { membrane to aid uremic } \\
\text { toxin transport out of the } \\
\text { cells via solvent drag }\end{array}$ \\
\hline Advantages & $\begin{array}{l}\text { Most widely used } \\
\text { profile; improves post } \\
\text { dialysis complications } \\
\text { and intradialytic } \\
\text { hypotension }\end{array}$ & $\begin{array}{l}\text { Significantly decreases } \\
\text { muscle cramps }\end{array}$ & $\begin{array}{l}\text { Decreases incidence of } \\
\text { disequilibrium syndrome }\end{array}$ \\
\hline Disadvantages & \multicolumn{2}{|l|}{$\begin{array}{l}\text { Less commonly used } \\
\text { profile } \\
\text { May increase incidence } \\
\text { of IDH }\end{array}$} & $\begin{array}{l}\text { Less commonly used profile } \\
\text { No significant aid in IDH }\end{array}$ \\
\hline
\end{tabular}




\title{
Figure legends
}

\section{Figure 1. Summary of literature search}

Figure 2. Crit-Line ${ }^{\circledR}$ monitor display of slopes. Profile A - Patient's plasma refill rate is occurring at the same or increased rate than the ultrafiltration. Profile B - No changes needed given the gradual slope and balance found between high ultrafiltration rate and avoidance of intradialytic symptoms. Profile C - Patient's display shows a steep slope representing a rapid decrease in blood volume and increases the risk of intradialytic symptoms. HCT hematocrit, BV - blood volume, SAT - saturation

Figure 3: Sodium profiling (modified from reference 20). A: Drawing depicts the movement of plasma sodium into dialysate fluid for eventual removal from patient. B: Representation of dialysate and plasma sodium trends using decreasing sodium profiling. Orange line indicates dialysate sodium trend via decreasing sodium profile. Yellow line indicates plasma sodium in response to profiling.

\section{Supplementary material}

\author{
Appendix A \& B. Search Strategy
}

Appendix C. Represented professional societies in consensus conference

Appendix D. Strength of Recommendation \& GRADE Level of Evidence (modified from references $6,7 \& 8$ ) 